Nama : Annisa Nurfadillah

Nim : 70200120035

Kelas : B

\title{
SUMBER ZAT GIZI DAN PENILAIAN STATUS GIZI
}

\section{A. Sumber zat gizi}

1) Karbohidrat

Karbobidrat merupakan zat gizi makro yang meliputi gula, pati dan serat. Gula dan pati memasok energi berupa glukosa, yaitu sumber energi utama untuk sel-sel darah merah, otak, sistem saraf pusat, plasenta dan janin. Glukosa dapat pula disimpan dalam bentuk glikogen dalam hati dan otot, atau diubah menjadi lemak tubuh ketika energi dalam tubuh berlebih. Gula tergolong jenis karbohidrat yang cepat dicerna dan diserap dalam aliran darah sehingga dapat langsung digunakan tubuh sebagai energi. Pati termasuk jenis karbohidrat yang lama dicerna dan diserap darah, karena perlu dipecah dulu oleh enzim pencernaan menjadi gula, sebelum dapat digunakan tubuh sebagai energi, tetapi ada beberapa jenis pati yang tahan terhadap enzim pencernaan. Sementara serat adalah jenis karbobidrat yang tidak dapat dicerna, sebab tidak dapat dipecah oleh enzim pencernaan, sehingga relatif utuh ketika melewati usus besar. Serat membantu memberikan perasaan kenyang, penting untuk mendorong buang air besar yang sehat, dan menurunkan risiko penyakit jantung koroner.

Gula dapat ditemukan secara alami pada buah, susu dan hasil olahnya, serta dapat dijumpai dalam bentuk ditambahkan pada makanan. Pati secara alami terdapat pada beras dan hasil olahannya (bihun, tepung beras), jagung, gandum dan hasil olahannya (terigu, roti, mie), pasta, sagu, umbi-umbian (ubi, singkong, kentang), sayuran, kacang kering. Sementara serat secara alami banyak terdapat pada sereal utuh, umbi-umbian, kacang-kacangan, sayuran, buah

Fungsi Kabohidrat

Dalam tubuh karbohidrat berperan sebagai penghasil energi utama sehingga kebutuhan tubuh akan karbohidrat diperhitungkan akan fungsinya sebagai penghasil energi. Jadi yang menjadi perhitungan ialah jumlah kalori yang diperlukan oleh tubuh. Energi ini dihasilkan oleh karbohidrat, lema dan protein. Dalam perhitungan kebutuhan energi ini jumlah kebutuhan energi yang berasal dari protein dan lemak dapat ditentukan secara tegas dengan mengingat satu gram protein menghasilkan empat kalori dan satu gram lemak menghasilkan sembilan kalori. Dengan demikian dapatlah dihitung jumlah kalori yang harus disumbangkan oleh karbohidrat, dengan rnemperhitungkan bahwa satu gram karbohidrat menghasilkan empat kalori. 
Selain berfungsi dalam menghasilkan eneiyi karbohidrat juga sebagai pemberi rasa manis pada makanan, mengatur metabolisme lemak, membantu pengeluaran feses dan sebagai penghemat protein.

\section{2) Protein}

Protein merupakan komponen struktur utama seluruh sel tubuh dan berfungsi sebagai enzim, hormon, dan molekul-molekul penting lain. Protein dikenal sebagai zat gizi yang unik sebab menyediakan asam-asam amino esensial untuk membangun sel-sel tubuh maupun sumber energi. Karena menyediakan "bahan baku" untuk membangun tubuh, protein disebut zat pembangun.

Protein terbentuk dari asam-asam amino dan bila asam asam amino tersebut tidak berada dalam keseimbangan yang tepat, kemampuan tubuh untuk menggunakan protein akan terpengaruh. Jika asam-asam amino yang dibutuhkan untuk sintesis protein terbatas, tubuh dapat memecah protein tubuh untuk memperoleh asam-asam amino yang dibutuhkan. Kekurangan protein memengaruhi seluruh organ dan terutama selama tumbuh kembang sehingga asupan protein kualitas tinggi yang memadai untuk kesehatan.

Kualitas protein sangat bervariasi dan tergantung pada komposisi asam amino protein dan daya cerna (digestibility). Protein hewani yang diperoleh dari telur, ikan, daging, daging unggas dan susu, pada umumnya adalah protein berkualitas tinggi. Adapun protein nabati yang diperoleh dari biji-bijian dan kacang-kacangan, pada umumnya merupakan protein berkualitas lebih rendah, kecuali kedelai dan hasil olahnya (tempe, tahu). Makanan yang tinggi daya cerna proteinnya (>95\%) ialah telur, daging sapi (98\%), susu sapi dan kedelai (95\%). Narnun, bila kacang-kacangan dan padi padian dikonsumsi secara kombinasi, protein nabati dapat membentuk protein lebih lengkap7

\section{.3) Lemak}

Lemak merupakan zat gizi makro, yang mencakup asam lemak dan trigliserida. Lemak adalah zat gizi yang padat energi (9 kkal per gram) sehingga lemak penting untuk menjaga keseimbangan energi dan berat badan. Lemak menyediakan medium untuk penyerapan vitaminvitamin larut lemak (vitamin A, D, E, K). Di dalam makanan, lemak berfungsi sebagai pelezat makanan sehingga orang cenderung lebih menyukai makanan berlemak. Tubuh manusia tidak dapat membuat asam lemak omega-6 dan omega-3 sehingga asam lemak ini adalah zat yang esensia17

\section{4) Vitamin}

Vitamin adalah senyawa organik yang tersusun dari karbon, hidrogen, oksigen dan terkadang nitrogen atau elemen lain yang dibutuhkan dalam jumlah kecil agar metabolisme, pertumbuhan dan perkembangan berjalan normal. Jenis nutrien ini merupakan zat-zat organik yang dalam kecil ditemukan pada berbagai macam makanan. Vitamin tidak dapat digunakan untuk 
rnenghasilkan energi.

Vitamin dapat dipilah menjadi 2 kelompok yaitu kelompok yang larut dalam lemak dan yang larut dalam air. Vitamin yang larut dalam lemak terdiri dari vitamin A, D, E dan K. Sedangkan vitamin yang larut dalam air terdiri dari vitamin B kompleks yang dibedakan menjadi 8 jenis vitamin yaitu vitamin B1 (Tiamin), vitamin B2 (Riboflavin), vitamin B3 (Niasin), vitamin B5 (Pantothenic Acid), vitamin B6 (Piridolasin), vitamin B7 (Biotin), vitamin B9 (Folat), vitamin B12 (Kobalamin) dan vitamin C8

5) Mineral

Mineral merupakan komponen anorganik yang terdapat dalam tubuh manusia. Sumber paling baik mineral adalah makanan hewani, kecuali magnesium yang lebih banyak terdapat dalam makanan nabati. Hewan memperoleh mineral dari tumbuh tumbuhan dan menumpuknya di jaringan tubuhnya.

Disamping itu mineral berasal dari makanan hewani mempunyai ketersediaan biologik lebih tinggi daripada yang berasal dari makanan nabati, makanan mengandung lebih sedikit bahan pengikat mineral daripada makanan nabati8

Menurut jenisnya. mineral dibedakan menjadi 2 yaitu:

a) Mineral organik, yaitu mineral yang dibutuhkan serta berguna bagi tubuh kita, yang dapat kita peroleh melalui makanan yang kita konsumsi setiap hari seperti nasi, ayam, ikan, telur, sayursayuran serta buah-buahan, atau vitamin tambahan.

b) Mineral anorganik, yaitu mineral yang tidak dibutuhkan serta tidak berguna bagi tubuh kita. Contohnya: timbal hitam $(\mathrm{Pb})$, iron oxide (besi teroksidasi), mercuri, arsenik, magnesium, aluminium atau bahan-bahan kimia hasil dari resapan tanah dan lain

Berdasarkan kebutuhan tubuh mineral dibedakan menjadi 2, yaitu:

a) Mineral makro, yaitu mineral yang dibutuhkan tubuh dalam jumlah lebih dari $100 \mathrm{mg}$ sehari.

b) Mineral mikro, yaitu kehutuhannya kurang dari 100 mg sehari

\section{B. Penilaian status gizi}

\section{Bentuk malnutrisi}

status gizi yaitu keadaan tubuh sebagai akibat konsumsi makanan dan penggunaan zat-zat gizi yang dibedakan menjadi beberapa kategori seperti gizi lebih, gizi baik, dan gizi. Status gizi tersebut dapat dipengaruhi oleh 2 hal pokok yaitu konsumsi makanan dan keadaan kesehatan tubuh atau infeksi . Dalam ilmu gizi baik kondisi gizi lebih maupun gizi kurang atau gizi buruk dimasukkan dalam Malnutrisi ( Gizi Salah). Malnutrisi disini merupakan suatu keadaan 
patologis akibat kekurangan atau kelebihan secara relatif ataupun absolut satu atau lebih zat gizi.

Terdapat empat bentuk malnutrisi, terdiri dari 1) Under nutrition yaitu kekurangan konsumsi pangan secara relatif atau absolut untuk periode tertentu), 2) Specific defisiency yaitu kekurangan zat gizi tertentu, 3) Over nutrition yaitu kelebihan konsumsi pangan dalam periode tertentu, dan 4) Imbalance, yaitu disporporsi zat gizi misalnya masalah kolesterol terjadi karena ketidakseimbangan fraksi lemak tubuh.Jadi jelaslah bahwa ternyata malnutrisi bukan hanya kurang gizi saja.

\section{Metode penilaian status gizi}

ada dua metode penilaian status gizi ini yaitu 1) Penilaian status gizi Langsung terdiri dari Antropometri, Klinis, Biokimia,Biofisik, 2) Tidak Langsung terdiri dari Survei Konsumsi Makanan, Statistik Vital, Faktor Ekologi. Dengan begitu banyaknya metode penilaian status gizi maka perlu dipertimbangkan faktor untuk memilih metode penilaianyaitu 1) Tujuan, 2) Unit Sampel yang akan diukur, 3) Jenis Informasi yang dibutuhkan, 4) Tingkat reliabilitas dan akurasi yang dibutuhkan, 5) Fasilitas \& peralatan yang ada, 6) Tenaga, 7) Waktu, 8) Dana yang tersedia.

\section{Penilaian status gizi secara langsung}

\section{a. Antropometri}

Antropometri digunakan untuk melihat ketidakseimbangan asupan protein dan energi (karbohidrat dan lemak). Keunggulan antropometri : Alat mudah, dapat dilakukan berulang ulang \& objektif, siapa saja bisa dilatih mengukur, relatif murah, hasilnya mudah disimpulkan, secara ilmiah diakui kebenarannya, sederhana, aman, bisa sampel besar, tepat, akurat, dapat menggambarkan riwayat gizi masa lalu, bisa untuk skrining \& mengevaluasi status gizi. Kelemahan antropometri meliputi : tidak sensitif \& spesifik mengukur suatu zat gizi, bisa dipengaruhi faktor diluar gizi misalnya penyakit, bisa terjadi kesalahan pengukuran.

Antropometri sebagai indikator status gizi dapat dilakukan dengan mengukur beberapa parameter. Parameter ini terdiri dari : 1) Umur, yaitu bulan penuh untuk anak 0-2 tahun dan tahun penuh >2tahun dihitung dari hari lahir, misalnya bayi usia 6 bulan 10 hari dihitung usia 6 bulan atau anak umur 8 tahun 4 bulan dihitung 8 tahun. 2) Berat Badan menggunakan timbangan yang sesuai dan cara yang tepat ,3)Tinggi Badan diukur pada posisi lurus dengan cara yang tepat, 4) Lingkar Lengan Atas dapat menggunakan pita LILA atau meteran, 5) Lingkar Kepala, 6) Lingkar dada, dan 7) Jaringan lunak (lemak sub cutan) diukur menggunakan alat khusus. Parameter sebagai ukuran tunggal belum bisa digunakan untuk menilai status gizi harus dikombinasikan. Kombinasi beberapa parameter disebut Indeks Antropometri yang terdiri dari : 1) Berat badan menurut umur (BB/U), 2) Tinggi badan menurut umur (TB/U), 3) Berat badan menurut tinggi badan (BB/TB), 4) Lingkar lengan atas menurut umur(LLA/U), Indeks Massa Tubuh (IMT),dll. Setiap indeks antropometri memiliki kelebihan dan kelemahan masingmasing misalnya BB/U kelebihannya : Mudah, cepat dimengerti, bisa mengukur status akut \& 
kronis, sensitif thd perubahan, dapat mendeteksi overweight, sedangkan kelemahannya : dipengaruhi ascites/udema, harus tahu jelas tanggal lahir, sering salah dalam pengukuran. TB/UKeuntungannya : alat mudah murah, fleksibel, bisa mengukur gizi masa lampau, sedangkan kelemahan : tinggi badan lambat berubah, posisi harus tepat, umur harus pasti, BB/TB Keuntungan : tidak perlu data umur, dpt membedakan proporsi badan gemuk, normal, kurus Kelemahan : Tidak memberikan gambaran tinggi anak menurut seumuran, sulit dilakukan pada balita, alat ukur 2 macam, lebih lama, sering terjadi kesalahan pengukuran. LLA/Ukeuntungannya : Baik utk menilai Kekurangan Energi Protein (KEP) berat, murah, mudah, kelemahannya : Sulit menentukan ambang batas, sulit menilai pertumbuhan anak 2-5 thn.

Klasifikasi lain untuk menentukan status gizi bisa menggunakan klasifikasi WHO berikut :

a. Gizi lebih bila BB saat ini : >120\% median BB/u baku WHO-NCHS

b. Gizi baik bila BB saat ini : 80\%-120\% median BB/u baku WHO-NCHS

c. Gizi sedang bila BB saat ini : 70\%-79,9\% median BB/u baku WHO-NCHS

d. Gizi kurangbila BB saat ini : 60\%-69,9\% median BB/u baku WHO-NCHS

e. Gizi buruk bila BB saat ini : $<60 \%$ median BB/u baku WHO-NCHS

\section{b. Pemeriksaan Klinis}

Pemeriksaan klinis sebagai salah satu metode penilaian status gizi secara langsung, secara umum terdiri dari dua bagian yaitu 1) riwayat medis / riwayat kesehatan merupakan catatan mengenai perkembangan penyakit, 2) pemeriksaan fisik, yaitu melakukan pemeriksaan fisik dari kepala sampai ujung kaki untuk melihat tanda-tanda dan gejala adanya masalah gizi

\section{c. Pemeriksaan Fisik}

Pemeriksaan fisik dapat dilakukan melalui teknik inspeksi atau periksa pandang, palpasi atau periksa raba, perkusi atau periksa ketuk dan auskultasi atau pemeriksaan menggunakan stateskop. Semua perubahan pada rambut, kulit, mata,mulut, lidah, gigi, kelenjar tiroid, dll. Menurut Jelliffe dan Jelliffe, tanda-tanda klinis dapat dikelompokkan dalam tiga kelompok besar yaitu 1) kelompok 1, tanda-tanda yang memang benar berhubungan dengan kurang gizi bisa karena kekurangan salah satu zat gizi atau kelebihan dari yang dibutuhkan tubuh, 2) kelompok 2, tanda-tanda yang membutuhkan investigasi atau penyelidikan lebih lanjut karena tanda ini mungkin saja merupakan tanda gizi salah atau mungkin disebabkan faktor lain, dan 3) tanda-tanda yang tidak berkaitan dengan gizi salah walaupun hampir mirip, untuk dapat menentukannya diperlukan keahlian khusus. Untuk dapat mengelompokan tanda-tanda yang ada pada pasien, pemeriksa harus mengetahui tanda-tanda dan gejala akibat kekurangan atau kelebihan setaip zat gizi. Kita ambil salah satu contoh pemeriksaan pada mata :Tanda-tanda 
pemeriksaan pada mata yang masuk kelompok 1 atau berhubungan dengan kekurangan gizi misalnya : konjungtiva anemis, keratomalasia, angular palpebritis, sedangkan masuk kelompok 2 yang mungkin berhubungan dengan kekurangan gizi misalnya : corneal vascularization, infeksi konjungtiva, arcus kornea, xanthomata, corneal scars. Tanda-tanda yang masuk kelompok 3 adalah pterygium

\section{d. Biofisik}

Penentuan status gizi dengan biofisik adalah melihat dari kemampuan fungsi jaringan dan perubahan struktur. Tes kemampuan fungsi jaringan meliputi kemampuan kerja dan energi ekspenditure serta adaptasi sikap. Tes perubahan struktur dapat dilihat secara klinis ( misalnya pengerasan kuku, pertumbuhan rambut,dll) atau non klinis (misalnya radiologi). Penilaian secara biofisik dapat dilakukan dengan tiga cara yaitu 1) uji radiologi, 2) tes fungsi fisik (misalnya tes adaptasi pada ruangan gelap), dan 3) sitologi (misalnya pada KEP dengan melihat noda pada epitel dari mukosa oral). Penilaian biofisik ini memerlukan biaya yang besar.

\section{Penilaian Status gizi tidak langsung}

\section{a. Survei konsumsi makanan}

Survei ini digunakan dalam menentukan status gizi perorangan atau kelompok. Survei konsumsi makanan dimaksudkan untuk mengetahui kebiasaan makan atau gambaran tingkat kecukupan bahan makanan dan zat gizi pada tingkat kelompok, rumah tangga dan perorangan serta faktorfaktor yang mempengaruhinya. Berdasarkan jenis data yang diperoleh, pengukuran konsumsi makanan menghasilkan dua jenis data yaitu kualitatif ( a.I frekuensi makanan, dietary history, metode telepon, dan daftar makanan) dan data kuantitatif ( a.I metode recall 24 jam, perkiraan makanan, penimbangan makanan, food account, metode inventaris dan pencatatan).

\section{b. Pengukuran Faktor Ekologi.}

Faktor ekologi yang berhubungan dengan malnutrisi ada enam kelompok yaitu, keadaan infeksi, konsumsi makanan, pengaruh budaya, sosial ekonomi, produksi pangan, serta kesehatan dan pendidikan.

\section{c. Statistik vital}

Beberapa statistik yang berhubungan dengan keadaan kesehatan dan gizi antara lain angka kesakitan, angka kematian, pelayanan kesehatan, dan penyakit infeksi yang berhubungan dengan gizi. Berikut ini dapat dijelaskan sebagai berikut 1) angka kematian berdasarkan umur adalah jumlah kematian pada kelompok umur tertentu terhadap jumlah rata-rata penduduk pada kelompok umur tersebut setiap 1.000 penduduk. Manfaat data ini mengetahui tingkat dan pola kematian menurut golongan umur dan penyebabnya. Misalnya angka kematian umur 2-5 bulan, umur 1-4 tahun, umur 13 - 24 bulan. Angka kesakitan dan kematian akibat penyebab tertentu, angka penyebab kematian pada umur 1-4 tahun merupakan informasi penting untuk menggambarkan keadaan gizi di suatu masyarakat. Kita lanjutkan dengan statistik layanan 
kesehatan misalnya Posyandu, Puskesmas, dan Rumah Sakit, berikutnya Infeksi yang Relevan dengan Keadaan Gizi. Statistik vital ini hanya berupa data pendukung, masih harus dikaji faktorfaktor lain yang berhubungan sehingga status gizi dapat ditentukan dengan akurat. Seperti metode yang lain statistik vital mempunyai kelemahan antara lain : data tidak akurat, adanya kesulitan dalam mengumpulkan data, dipengaruhi oleh kemampuan menginterpretasikan data secara tepat. 


\section{DAFTAR PUSTAKA}

http://bppsdmk.kemkes.go.id/pusdiksdmk/wp-content/uploads/2017/08/Ilmu-GiziKeperawatan-Komprehensif.pdf

http://repositori.uin-alauddin.ac.id/17794/

http://repository.unp.ac.id/1127/1/ANTON\%20KOMAINI_113_11.pdf

http://eprints.poltekkesjogja.ac.id/1333/4/Chapter\%202.pdf

https://eprints.uny.ac.id/8842/2/bab2\%20-09604227098.pdf

http://www.pustaka.ut.ac.id/lib/wp-content/uploads/pdfmk/PEBI4428-M1.pdf 